\title{
Post-cyclic transmission in Acanthocephalus tumescens (Acanthocephala: Echinorhynchidae)
}

\author{
Carlos A. Rauque, Liliana G. Semenas and Gustavo P. Viozzi
}

Laboratorio de Parasitología, Centro Regional Universitario Bariloche, Universidad Nacional del Comahue, Quintral 1250 , (8400) San Carlos de Bariloche, Río Negro, Argentina

Key words: post-cyclic transmission, Acanthocephalus tumescens, Oncorhynchus mykiss, Galaxias maculatus

\begin{abstract}
The aim of this study was to investigate the post-cyclic transmission of Acanthocephalus tumescens (von Linstow, 1896) from Galaxias maculatus Jenyns to Oncorhynchus mykiss (Walbaum). Wild G. maculatus naturally infected with A. tumescens were fed to cultured rainbow trout, which were sacrificed at the second, third and fourth weeks post infection. Normally attached male and female acanthocephalans were recovered alive from the intestine of rainbow trout. Parasites survive at least four weeks post infection, growing and attaining full sexual maturity. Prevalence and mean intensity generally decreased after infection. A. tumescens is the eighth acanthocephalan species in which post-cyclic transmission has been proven.
\end{abstract}

Post-cyclic transmission occurs when a parasite survives, grows and matures in the predator of their definitive host (Nickol 1985, Kennedy 1999), and this could explain the wide host range of some species (Lassiere and Crompton 1988). It could be potentially important in nature due to the increase of the dispersion of parasites among their fish hosts. However, its importance has been disputed because it has only been recorded in a few species and not in all their stages of development (Kennedy 1999). This kind of transmission has been previously reported from seven species of acanthocephalans, Acanthocephalus ranae (Schrank, 1788); Echinorhynchus salmonis Müller, 1784; Moniliformis moniliformis (Bremser, 1811); Neoechinorhynchus cristatus Lynch, 1936; N. rutili (Müller, 1780); Octospiniferoides chandleri Bullock, 1957 and Pomphorhynchus laevis (Müller, 1776) (Nickol 1985, Lassiere and Crompton 1988, Kennedy 1999).

Acanthocephalus tumescens (von Linstow, 1896) is one of the two species of acanthocephalans parasitising fish from Andean Patagonian lakes. Its intermediate host is the amphipod Hyalella patagonica Ortmann and the definitive hosts are the native fishes Galaxias maculatus Jenyns, G. platei Steindachner, Diplomystes viedmensis (MacDonagh), Odontesthes hatcheri (Eigenmann), Percichthys trucha (Cuvier and Valenciennes) and $P$. colhuapiensis MacDonagh and the introduced fishes: Oncorhynchus mykiss (Walbaum), Salmo trutta (Linnaeus), S. salar Linnaeus, Salvelinus fontinalis (Mitchill) and $S$. namaycush (Walbaum) (Torres et al. 1990, 1992, Ortubay et al. 1994, Semenas and Trejo 1997, Trejo et al. 2000). Salmonids were introduced in Patagonia at the beginning of the 20th century (Navas 1987) and they are all predators of native fishes (Macchi et al. 1999), eating especially small ones like $G$. maculatus. This trophic relationship makes post-cyclic transmission possible.

This phenomenon has not previously been recorded in fish parasite species of the genus Acanthocephalus and this type of transmission has not been experimentally studied in fishes from Argentina. The aim of this work was therefore to investigate the possibility of such transmission in Acanthocephalus tumescens from wild G. maculatus to cultured $O$. mykiss.

\section{MATERIALS AND METHODS}

Galaxias maculatus (puyen chico) is an abundant smallsized fish species, and is a suitable wild host for A.tumescens as the parasite can reach full sexual maturity (Trejo et al. 2000).

Samples of wild G. maculatus infected with A. tumescens were taken from Lake Mascardi $\left(41^{\circ} 17^{\prime} \mathrm{S}, 71^{\circ} 38^{\prime} \mathrm{W}\right.$, Río Negro, Argentina). The captured fish were immediately brought to the laboratory and kept alive for up to three days until examined. The samples were divided into control and source groups. The control group fish were killed and musculature and all organs examined by standard methods. All the recovered acanthocephalans were located in the intestine. The parasites were counted, sexed and measured from the neck to the end of the body $(\mu \mathrm{m})$. The female parasites were assigned to one of three categories: F1, immature with ovarian balls only; F2 with maturing eggs and F3 with fully mature shelled eggs. The evaluation of maturity was based on the percentage of gravid females (F2 + F3). The source group fish were killed to be fed to cultured rainbow trout. The rainbow trout were all of similar size $(30 \mathrm{~cm})$ and were obtained from a local fish farm known to be free of infection with $A$. tumescens. Forty-eight hours previous to the infection, rainbow trout were isolated and maintained without food. Each fish was anaesthetised with benzocaine solution, force fed with one puyen, allowed to recover and monitored to detect possible vomit. They were fed regularly on trout pellets

Address for correspondence: L.G. Semenas, Laboratorio de Parasitología, Centro Regional Universitario Bariloche, Universidad Nacional del Comahue, Quintral 1250, (8400) San Carlos de Bariloche, Río Negro, Argentina. Phone: ++54 2944 423374; Fax: ++54 2944 422111; E-mail: 1semenas@crub.uncoma.edu.ar 
and sacrificed at the second, third and fourth weeks post infection. Rainbow trout were examined for acanthocephalans by standard methods and all parasites were counted, sexed and measured and the females assigned to one of the three categories previously stated.

Two different experiments were performed. In experiment 1 the presence of acanthocephalans in G. maculatus was not checked and in experiment 2 the wild fish were necropsied to detect and count the acanthocephalans that could be seen through the transparent wall of the digestive tube, so the source group was only formed of infected fish. Data of number of fish in each experiment are shown in Tables 1 and 2.

The following tests were performed: contingency tables to test differences among female maturity, Mann-Whitney test to check differences between length of males and females in control group and experimentally infected acanthocephalans, and Wilcoxon test to determine differences in sex ratio. Significance levels were $95 \%$ for all the tests.

\section{RESULTS}

Normally attached male and female acanthocephalans were recovered alive from the intestine of rainbow trout in both experiments. The parasites survived at least four weeks post infection (Tables 1 and 2).

In experiment 1 (Table 1), the 46 recovered acanthocephalans represented $25 \%$ of the control group parasites. Both prevalence and mean intensity of $A$. tumescens decreased after infection. All the parasites increased their length after infection but only the females were significantly longer $(Z=-2.88 ; P<0.05$; $\mathrm{n}=158$ ). Proportion of females was larger than males in the control group and this difference increased after infection. Gravid females (F2 + F3) increased significantly after infection $(\mathrm{T}=11.98 ; \mathrm{P}<0.05 ; \mathrm{n}=6)$.

In experiment 2 (Table 2 ), the 78 recovered acanthocephalans represented $19 \%$ of the control group parasites. Both prevalence and mean intensity of $A$. tumescens decreased after infection. Males $(\mathrm{Z}=-5.14$; $\mathrm{P}<0.05 ; \mathrm{n}=201)$ and females $(\mathrm{Z}=-2.46 ; \mathrm{P}<0.05 ; \mathrm{n}=$ $257)$ significantly increased their length after infection. The proportion of females was larger than males in the control group and this relationship was reversed after infection. Gravid females (F2 + F3) increased significantly after infection $(\mathrm{T}=7.76 ; \mathrm{P}<0.05 ; \mathrm{n}=6)$. If the comparisons are made with the source group, the 78 recovered acanthocephalans represented $37 \%$, prevalence decreased and mean intensity was similar after infection.

\section{DISCUSSION}

Laboratory experiments on several species of acanthocephalans have shown they can survive in a predator host between 7 and 84 days (Hnath 1969, Uglem and Beck 1972, Lassiere and Crompton 1988, Kennedy 1999). In our experiments, the specimens of Acanthocephalus tumescens survived for four weeks,

Table 1. Characteristics of infection with Acanthocephalus tumescens in Galaxias maculatus and Oncorhynchus mykiss in experiment 1 .

\begin{tabular}{|c|c|c|c|c|c|c|}
\hline & \multirow{2}{*}{ Control group } & \multirow{2}{*}{ Source group } & \multicolumn{3}{|c|}{ Weeks post infection } \\
\hline & & & & Second & Third & Fourth \\
\hline \multicolumn{2}{|c|}{ Number of fish } & 22 & 22 & 7 & 7 & 8 \\
\hline \multicolumn{2}{|c|}{ Number of parasites } & 183 & $?$ & 23 & 12 & 11 \\
\hline \multicolumn{2}{|l|}{ Prevalence } & $59 \%$ & ? & $43 \%$ & $14 \%$ & $50 \%$ \\
\hline \multicolumn{2}{|c|}{ Mean intensity \pm SD } & $14 \pm 17.0$ & $?$ & $8 \pm 3.5$ & $12 \pm 0.0$ & $3 \pm 2.3$ \\
\hline Length $(\mu \mathrm{m})$ & M & $3387 \pm 234.5$ & ? & $3522 \pm 415.5$ & $2499 \pm 361.5$ & $4047 \pm 291.0$ \\
\hline $\bar{X} \pm \mathrm{SD}$ & $\mathrm{F}$ & $4563 \pm 571.0$ & $?$ & $5358 \pm 493.5$ & $4646 \pm 270.0$ & $5554 \pm 711.0$ \\
\hline \multicolumn{2}{|c|}{ Sex ratio $F: M$} & $2: 1$ & ? & $3.6: 1$ & $5: 1$ & $4.5: 1$ \\
\hline \multicolumn{2}{|c|}{ Percentage of gravid females } & 65 & ? & 100 & 70 & 100 \\
\hline
\end{tabular}

Table 2. Characteristics of infection with Acanthocephalus tumescens in Galaxias maculatus and Oncorhynchus mykiss in experiment 2 .

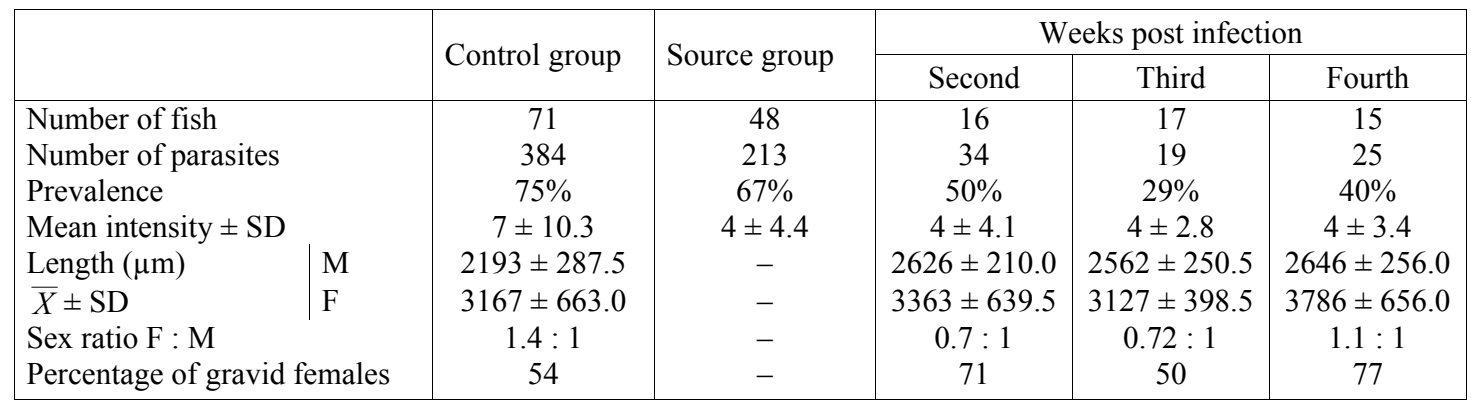


increasing in length, and females reached full sexual maturity after infection in rainbow trout. So it is the eighth acanthocephalan species in which post-cyclic transmission has been proven (Nickol 1985, Lassiere and Crompton 1988, Kennedy 1999) and also the first record of post-cyclic transmission in fish parasite species of the genus Acanthocephalus, since $A$. ranae is an amphibian parasite.

If the parasite remains alive long enough in the predator fish, post-cyclic transmission could be important in nature. Kennedy (1999) suggested that only Echinorhynchus salmonis and Pomphorhynchus laevis survived long enough to consider post-cyclic transmission potentially important in natural cycles. In the case of $P$. laevis the parasites were normally attached, grew and survived 31 days post infection in rainbow trout although the females did not attain full sexual maturity (Kennedy 1999) and in E. salmonis they survived up to 84 days post infection (Hnath 1969) but maturity was not considered. In our experiments, the parasites could attach normally, survived, grew and matured in rainbow trout, so this transmission could be potentially important in nature and the post-cyclic parasites infecting migrating salmonids could increase their distribution. This transmission could explain the large host range of this acanthocephalan in Andean Patagonian lakes (Ortubay et al. 1994).

Host's age and sex (Esch and Fernández 1993), behavioural changes and morphology (Kennedy 1975) and the existence of paratenic and post-cyclic hosts (Nickol 1985) can influence the transmission rate. The impossibility of obtaining a reliable estimate of numbers of parasites fed to predator fishes in this type of experiments makes the calculation of transmission rate difficult due to over-dispersion (Kennedy 1999). In an attempt to surmount this problem, in experiment 2 the parasites were counted through the transparent intestine wall of $G$. maculatus before feeding to the rainbow trout, although the viability of parasites, especially the females could be affected by the manipulation. A transmission rate between $25 \%$ and $37 \%$ was calculated but it could be an underestimate because of a probable loss of parasites in the third and fourth week post infection. The decrease of prevalence and mean intensity could be attributed to a natural loss of parasites related to differential transmission rate between sexes and state of maturity. The higher proportion of females in rainbow trout than in G. maculatus in experiment 1 and the increasing proportion of females in rainbow trout from the first to fourth week post infection in both experiments would suggest that females of $A$. tumescens have a higher transmission rate than males and that males would leave the host before females do. This reproductive strategy has been suggested as a way to avoid intraspecific competition (Crompton 1985). The lower proportion of females in rainbow trout than in $G$. maculatus could be related to the manipulation of the digestive tract during experimental infection.

Kennedy (1999) suggested that Pomphorhynchus laevis did not remain long in rainbow trout, as specimens did not mature after 31 days post infection and sex ratio did not change. In this study, a decreasing proportion of males and an increasing proportion of F2 and F3 females after infection would suggest that transmitted acanthocephalans were involved in reproductive processes. Kennedy (1999) suggested that the state of development of the bulb, which is correlated with age, limits the possibility of transmitting big specimens of $P$. laevis. This would not be the situation in big specimens of $A$. tumescens, which can be transmitted because no host tissue response and encapsulation occur in this acanthocephalan species.

Acknowledgements. We are very grateful to N. Luxich and V. Baéz from the Vivero de Salmónidos of Bariloche for technical support during the experiments. Funds were provided by UNC 092 and PICT FONCYT 01-00002-00067-A.

\section{REFERENCES}

CROMPTON D.W.T. 1985: Reproduction. In: D.W.T. Crompton and B.B. Nickol (Eds.), Biology of the Acanthocephala. Cambridge University Press, Cambridge, pp. 213-271.

ESCH G.W., FERNÁNDEZ J.C. 1993: A Functional Biology of Parasitism. Chapman \& Hall, London, 337 pp.

HNATH J.G. 1969: Transfer of an adult acanthocephalan from one fish host to another. Trans. Am. Fish. Soc. 98: 332.

KENNEDY C.R. 1975: Ecological Animal Parasitology. Blackwell Scientific Publications, Oxford, London, Edinburgh, Melbourne, 163 pp.

KENNEDY C.R. 1999: Post-cyclic transmission in Pomphorhynchus laevis (Acanthocephala). Folia Parasitol. 46: 111-116.

LASSIERE O.L., CROMPTON D.W.T. 1988: Evidence for post-cyclic transmission in the life history of Neoechino- rhynchus rutili (Acanthocephala). Parasitology 97: 339343.

MACCHI P.J., CUSSAC V.E., ALONSO M.F., DENEGRI M.A. 1999: Predation relationships between introduced salmonids and the native fish fauna in lakes and reservoirs in Northern Patagonia. Ecol. Freshw. Fish 8: 227-236.

NAVAS J.R. 1987: Los vertebrados exóticos introducidos en la Argentina. Rev. Mus. Argent. Cienc. Nat. "Bernardino Rivadavia" Zool. 14: 7-38.

NICKOL B.B. 1985: Epizootiology. In: D.W.T. Crompton and B.B. Nickol (Eds.), Biology of the Acanthocephala. Cambridge University Press, Cambridge, pp. 307-346.

ORTUBAY S.G., SEMENAS L.G., ÚBEDA C.A., QUAGGIOTTO A.E., VIOZZI G.P. 1994: Catálogo de peces dulceacuícolas de la Patagonia argentina y sus 
parásitos metazoos. Dirección de Pesca, Rio Negro, Argentina, $110 \mathrm{pp}$.

SEMENAS L., TREJO A. 1997: Redescription of Acanthocephalus tumescens (von Linstow, 1896) (Palaeacanthocephala: Echinorhynchidae) in Galaxias maculatus (Pisces: Galaxiidae) in Patagonia (Argentina). Syst. Parasitol. 36: 13-16.

TORRES P., CONTRERAS A., CUBILLOS V., GESCHE W., MONTEFUSCO A., REBOLLEDO C., MIRA A., ARENAS J., MIRANDA J.C., ASENJO S., SCHLATTER R. 1992: Parasitismo en peces, aves piscívoras y comunidades ribereñas de los Lagos Yelcho y TaguaTagua, X Región de Chile. Arch. Méd. Vet. (Valdiviva) 24: 77-92.
TORRES P., RUIZ E., REBOLLEDO C., MIRA A., CUBILlOS V., NAVARRETE N., GESCHE W., MONTEFUSCO A., VALDES L., ALBERDI A. 1990: Parasitismo en peces y comunidades humanas ribereñas de los Lagos Huillinco y Natri (Isla Grande de Chiloé), Chile. Bol. Chil. Parasitol. 45: 47-55.

TREJO A., SEMENAS L., VIOZZI G. 2000: Acanthocephalus tumescens (Acanthocephala, Echinorhynchidae) in Galaxias maculatus (Pisces, Galaxiidae) of lake Gutiérrez, Patagonia, Argentina. J. Parasitol. 86: 188-191.

UGLEM G.L., BECK S.M. 1972: Habitat specificity and correlated aminopeptidase activity in the acanthocephalans Neoechinorhynchus cristatus and N. crassus. J. Parasitol. 58: 911-920.

Accepted 31 July 2001 